\title{
In fighting common threats, people's deep commitment to taking collective action matters: examples from China's COVID-19 battle and her other combats
}

\author{
Hannah Catherine Palko ${ }^{1}$ (D) Wei-Ning Xiang ${ }^{1}$
}

Received: 18 May 2020 / Accepted: 11 June 2020

(c) Springer Nature Singapore Pte Ltd. 2020

\begin{abstract}
In fighting against common threats to human survival and well-being, be they from natural disaster or human conflict, people's commitment to taking collective action matters and can make a huge or even decisive difference. Throughout human history, there is a myriad of powerful examples from around the world in which people's deep commitment to taking collective action changed the course of combat against common threats. These examples are invaluable heritages that belong to the entire humanity. At this critical juncture in human history, they can help cultivate a greater sense of optimism among all the people in the world both in the present fight against the COVID-19 pandemic and beyond. To this end, in this showcase article, we present examples of this kind from China's ongoing COVID-19 battle, and from two of her many historical combats.
\end{abstract}

Keywords The COVID-19 pandemic $\cdot$ Common threats $\cdot$ Human survival and well-being $\cdot$ Collective action $\cdot$ China $\cdot$ WHO · Yoshiaki Yoshimi · Owen Lattimore

\section{WHO: fighting the common threat collectively made a decisive difference}

In February 2020, a team of 25 experts from 9 countries spent 9 days (February 16-24) in China working on a World Health Organization's project entitled The WHO-China Joint Mission on Coronavirus Disease 2019 (COVID-19) [the Joint Mission, thereafter]. ${ }^{1}$ After a series of intensive field work across the country, including a two-day visit to the country's hardesthit city Wuhan (Fig. 1), the Joint Mission team released its 40-page report on February 28, 2020 (The Joint Mission 2020).

\subsection{A rigorously implemented public health approach made a huge difference}

The team was most impressed with "the apparent efficacy" of a "bold" yet "science-based, risk informed and phased

Hannah Catherine Palko

hpalko@uncc.edu

Wei-Ning Xiang

wxiang@uncc.edu

1 University of North Carolina at Charlotte, Charlotte, NC 28223, USA approach" to containing the COVID-19 virus transmission (The Joint Mission 2020, p. 17, p. 18). ${ }^{2}$ In the Joint Mission report, it writes (Ibid., p. 17; parentheses by the authors of this article):

\footnotetext{
${ }^{1}$ [1] COVID-19: "a mild to severe respiratory illness that is caused by a coronavirus (Severe acute respiratory syndrome coronavirus 2 of the genus Betacoronavirus), is transmitted chiefly by contact with infectious material (such as respiratory droplets), and is characterized especially by fever, cough, and shortness of breath and may progress to pneumonia and respiratory failure. NOTE: COVID-19 was first identified in Wuhan, China in December 2019." (Merriam-Webster 2020a) [2] About China's releasing of the COVID-19 information to WHO after the virus was identified, the Associate Press published an article on June 2, 2020, entitled China delayed releasing coronavirus info, frustrating WHO (The Associate Press 2020).

2 In direct contrast to the idea underlying this approach is a bold, non-science-based, risk-laden idea. At the daily COVID-19 briefing on April 23, 2020, the US President Donald Trump publicly suggested that medical doctors study the idea of people receiving injections of disinfectant to combat the coronavirus (Smith and Paul 2020). The comment was denounced fiercely by medical doctors, health experts, and even disinfectant manufacturers as being not just ignorant but actively dangerous (Brown and Sink 2020; Smith 2020). The next day, President Trump claimed that he was being "sarcastic." The claim is undermined by video of the April 23 briefing (Smith and Paul 2020) and stirred up a $900 \%$ surge in lookup for the words sar-
} 


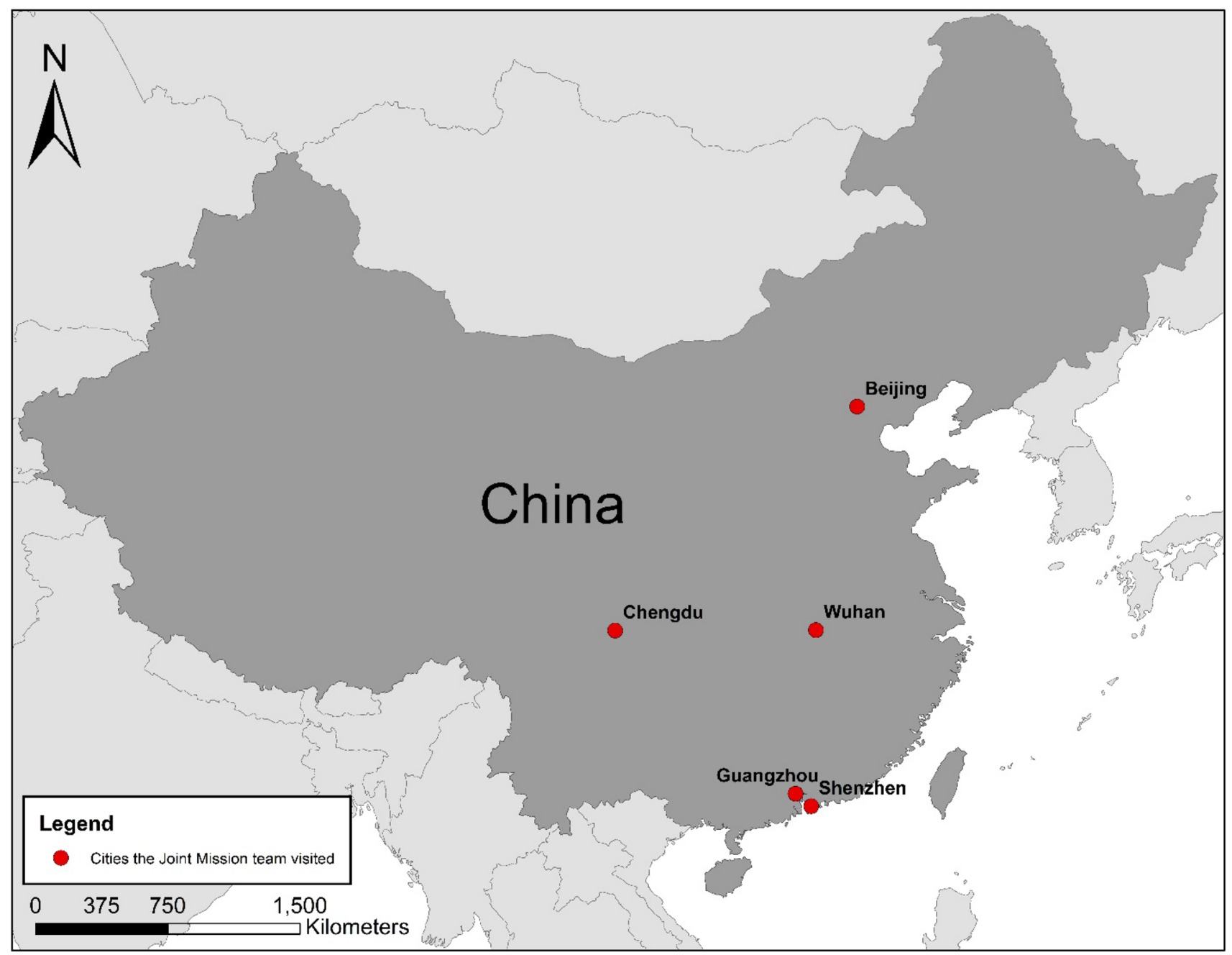

Fig. 1 Cities the Joint Mission team visited. [Map based on Annex B Summary agenda of the mission in the Joint Mission report (The Joint Mission 2020, pp. 25-26)]

China's bold (yet "science-based, risk informed and phased") approach ... has changed the course of a rapidly escalating and deadly epidemic. A particularly compelling statistic is that on (February 10) the first day of the advance team's work there were 2478 newly confirmed cases of COVID-19 reported in China. Two weeks later, on the final day of this Mission (February 24), China reported 409 newly confirmed cases.

\section{Footnote 2 (continued)}

casm and sarcastic on April 24 in Merriam-Webster.com dictionary (Merriam-Webster 2020b).
This decline in COVID-19 cases across China is real (Fig. 2). ${ }^{3}$

The team was equally impressed with "the uncompromising rigor" the nation demonstrated in implementing such a

${ }^{3}$ [1] On April 25, 2020, the authors of this article double checked the updated confirmed cases. WHO (https://covid19.who.int/): 2985 (February 10, 2020), 221 (February 24, 2020); Worldometer (https:// www.worldometers.info/coronavirus/country/china/): 2467 (February 10, 2020), 508 (February 24, 2020); Johns Hopkins University (https://coronavirus.jhu.edu/map.html): 2525 (February 10, 2020), 219 (Feb 24, 2020). Despite the discrepancies in numbers, data from these sources show the same declining trend during the two-week period and onward. [2] About "the first day of the advance team's work", the team provides the following information in Annex B of the report (The Joint Mission 2020 p. 25; parenthesis by the authors of this article): "10-15 February 2020, Beijing, Advance Team and WHO Country team meetings with (Chinese) national counterparts and institutions." It provides no information in the report about the nature and composition of the advance team. 
Fig. 2 Confirmed daily COVID19 cases in China, January 22, 2020-May 4, 2020. Source:

Johns Hopkins University Center for Systems Science and Engineering, https://data.humda ta.org/dataset/novel-coronaviru s-2019-ncov-cases. Accessed 5 May 2020

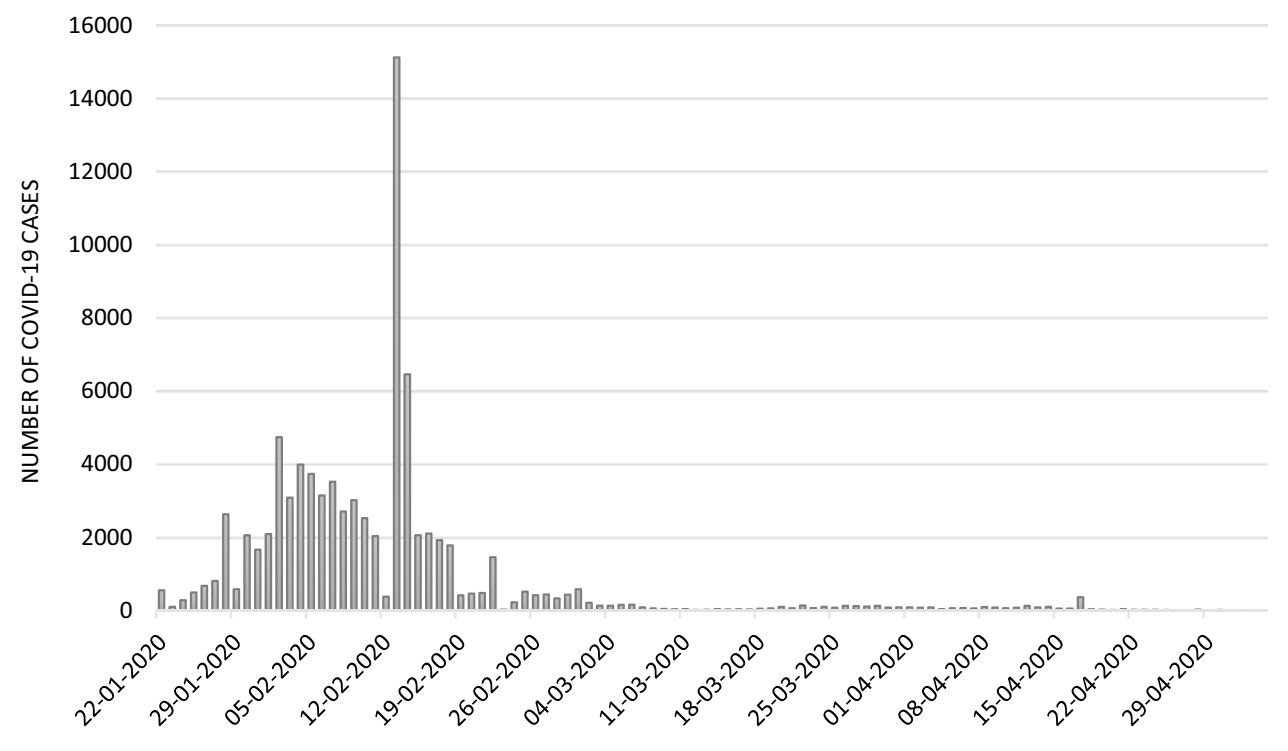

prudent public health approach (The Joint Mission 2020, p. 17):

In the face of a previously unknown virus, China has rolled out perhaps the most ambitious, agile and aggressive disease containment effort in history (Ibid., p. 16).... China's uncompromising and rigorous use of non-pharmaceutical measures (under its "sciencebased, risk informed and phased approach") to contain transmission of the COVID-19 virus in multiple settings provides vital lessons for the global response (Ibid., p. 19; parenthesis by the authors of this article). ${ }^{4}$

\subsection{People's deep commitment to taking collective action was a sine quo non}

The team attributes this significant advance on the battleground to, on top of other factors, the resolute, compassionate support from the people in China. ${ }^{5}$ It praises (The Joint Mission 2020, p. 17; parentheses by the authors of this article):

Achieving China's exceptional coverage with and adherence to these containment measures has only been possible due to the deep commitment of the

\footnotetext{
${ }^{4}$ Since then, China has shared her experiences with more than 150 countries and international organizations via 70 videoconferences; provided medical supplies to more than 125 countries and 4 international organizations, as well as sent medical teams to 16 countries (Chik 2020; Liu 2020).

5 People's compassionate support can come in different forms (The Dalai Lama 2020; Douglas 2020; Hu 2020). "[A] compassionate or constructive act-whether working in hospitals or just observing social distancing - has the potential to help many." (Dalai Lama 2020).
}

Chinese people to collective action in the face of this common threat. At a community level this is reflected in the remarkable solidarity of provinces and cities in support of the most vulnerable populations and communities. Despite ongoing outbreaks in their own areas, Governors (of the provinces) and Mayors have continued to send thousands of health care workers and tons of vital PPE (personal protective equipment) supplies into (the hardest-hit) Hubei province and (its capital) Wuhan city. ${ }^{6}$

At the individual level, the Chinese people have reacted to this outbreak with courage and conviction. They have accepted and adhered to the starkest of containment measures-whether the suspension of public gatherings, the month-long "stay at home" advisories or prohibitions on travel. ${ }^{7}$

\footnotetext{
6 "More than 42,000 medical workers around the country came to Hubei (and its capital city Wuhan) to work shoulder by shoulder with their local peers in battling COVID-19. The last medical team left the province on Wednesday (April 15, 2020) as the number of remaining COVID-19 patients dropped below 150." (Zou 2020, parentheses by the authors) On February 21, a group of volunteer photographers from Beijing kicked off a massive project in Wuhan to take a headshot photograph for each and every one of the 42,000-plus medical workers. In about a month, they wrapped up the project (Ibid.). This is yet one of many examples for compassionate actions volunteers took during the COVID-19 battle.

7 [1] Wuhan city government announced the citywide lockdown on January 23, 2020, and ended it on April 8. Its 76-day lockdown record is the highest among major Chinese cities. [2] Among newspaper articles on the efficacy of the stark lockdown strategy in China's COVID-19 battle is a March 19, 2020, article in The Guardian written by two reporters based in Shanghai, China. It has a striking yet
} 


\subsection{EndCoronavirus: China is among the $\mathbf{4 2}$ "countries beating COVID-19"}

On February 29, 2020, the day after the Joint Mission team released its report, an international volunteer coalition EndCoronavirus was formed. Since then, a research team in the organization, led by American complex system scientist Yaneer Bar-Yam, has been tracking and analyzing the global response to the COVID-19 pandemic (EndCoronavirus 2020). In the team's real-time, country-by-country assessment report, China, with her continuing progress after the Joint Mission team's visit, is listed among the 42 countries or regions that are "winning" the battle by "beating COVID-19" (Ibid.; as of May 15, 2020). ${ }^{8}$

\subsection{Trump: "Great discipline is taking place in China"}

It is noteworthy that the high praise the Joint Mission team issued for the Chinese people's deep commitment to collective action resonates an admiring remark the US President Donald Trump made 9 days before the team's visit to China. On February 7, reflecting on "a long and very good conversation (he "just had") by phone with President Xi of China," President Trump twitted, "Great discipline (of the government and the public) is taking place in China, as President $\mathrm{Xi}$ strongly leads what will be a very successful operation (to counterattack the COVID-19 virus)." [https://twitter.com/ realDonaldTrump/status/1225728756456808448 (accessed May 5, 2020); parentheses by the authors of this article] ${ }^{9}$

\section{Footnote 7 (continued)}

telling title: China's coronavirus lockdown strategy: brutal but effective (Graham-Harrison and Kuo 2020). [3] In two communication essays published in this journal, Chinese scholar-practitioner Yuncai Wang, ecologists Liding Chen and Xingzhong Yuan reflect on the rigorously implemented lockdown strategy through their own workat-home experiences in, respectively, Shanghai, Beijing, and Chongqing. See Wang (2020) and Chen and Yuan (2020). [4] During the lockdown, besides medical workers, many people also risked their health to keep the country running. TIME magazine ran a cover story on March 16, 2020, featuring delivery drivers during the coronavirus epidemic (Campbell 2020).

8 Other "winning" countries or regions on the list (as on May 15, 8:30 pm US EDT) are all much less populous: Albania, Andorra, Australia, Barbados, Belize, Bhutan, Burkina Faso, Cambodia, Costa Rica, Croatia, Cuba, Cyprus, Djibouti, Estonia, Georgia, Greece, Iceland, Jamaica, Jordan, Kosovo, Latvia, Lebanon, Liechtenstein, Lithuania, Luxembourg, Mali, Malta, Mauritius, Monaco, Montenegro, New Zealand, Niger, San Marino, Slovakia, Slovenia, Sri Lanka, Taiwan, Thailand, Tunisia, Uruguay, and Vietnam (EndCoronavirus 2020).

${ }^{9}$ Since then, however, President Trump and his administration have been critically attacking the Chinese government for its handling of COVID-19 pandemic. For a TIME magazine commentary on the administration's strategy, see Dozier (2020).

\section{History: fighting common threats collectively has saved China many times}

The kind of compliments abovementioned comes as no surprise at all to those who are familiar with China's culture and history. People's deep commitment to taking collective action in fighting common threats is indeed a hallmark of this "oldest living civilization in the world" (American Historical Association Historical Service Board 1944, p. 59; Makeham 2008). ${ }^{10}$ Solidarity, participation, discipline, and readiness for self-sacrifice, among other forms of this commitment, have enabled the Chinese people to overcome extreme difficulties and survive unpredictable vicissitudes in nature and life for more than 5000 years. As such, what the Joint Mission team observed, the EndCoronavirus team discovered, and President Trump learnt in 2020 is nothing other than a recurring instance, the latest in China's history, of nationwide, efficacious collective action in the face of a calamity.

\subsection{People's collective action in the combat against SARS pandemic (2003)}

A recent example is the battle against SARS pandemic in 2003. ${ }^{11}$ After a period of uncertainty and confusion in the

\footnotetext{
${ }^{10}$ Here we define "a common threat" as a danger, something or someone that can hurt or harm people, that might happen to every individual human being in a certain place. A common threat comes either from a natural disaster or human conflict to which no one in a certain place (e.g., the earth, a country, a region, a city, a village, a community, etc.) is immune. At the global scale, for example, the COVID-19 pandemic exemplifies the former, and World War II the latter; at a regional scale, one such example is the pernicious hardships of water shortage people in the Linxian County, Henan Province, China had been enduring before the construction of the Red Flag Canal (Xiang 2019). A broader definition of common threat that includes all the beings in a certain place is possible but not used in this article.

${ }^{11}$ [1] Severe acute respiratory syndrome (SARS): "a severe respiratory illness that is caused by a coronavirus (species Severe acute respiratory syndrome-related virus of the genus Betacoronavirus), is transmitted especially by contact with infectious material (such as respiratory droplets or body fluids), and is characterized by fever, headache, body aches, a dry cough, hypoxia, and usually pneumonia." (Merriam-Webster 2020C) [2] For comprehensive reviews and critical assessments of the global response to the 2003 SARS pandemic, readers will find the following publication informative and useful: Learning from SARS: preparing for the next disease outbreak-workshop summary (Knobler et al. 2004). [3] Readers will particularly enjoy reading an article in the volume entitled The SARS epidemic and its aftermath in China: a political perspective (Huang 2004). In the article, Chinese-American political scientist Yanzhong Huang provides a comprehensive, critical yet constructive review of the nationwide SARS battle in China, its antecedents and aftermath. Many of his insights shed light on the 2020 global response to the COVID-19 pandemic, including the battle in China.
} 
early stage of the pandemic (Huang 2004, pp. 117-123), the Chinese people collectively waged a "nationwide war on SARS" the government declared on April 20, 2003, with the aim "to halt the epidemic" (Mahmoud and Lemon 2004, p. 14). Besides adhering to a series of large-scale quarantine measures, people partook in a mass "Patriotic Health Campaign" (Huang 2004, p. 125), which was initiated by Chairman Mao Zedong in 1952 when the country was plagued with epidemic diseases and shortages of medicine (China. org.cn 2020). In the hardest-hit Guangdong Province alone, for example, 80 million people were mobilized to clean houses and streets; in the countryside, virtually every village was on SARS alert, with roadside booths installed to examine people who entered or left (Huang 2004, p. 125). With the widespread, steadfast support from the whole people, this government-led, nationwide "crusade against SARS" (Ibid., p. 117) triumphed on August 16, 2003 with the last two SARS patients discharged from a hospital in Beijing (Ibid., p. 125).

\subsection{People's collective action in the resistance against Japanese aggression (1931-1945)}

From 1939 to 1940 during the second Sino-Japanese war, ${ }^{12}$ according to Japanese historian Yoshiaki Yoshimi (吉見義 明), “Japan not only expended more than ten billion yen and suffered more than one hundred thousand deaths in (its aggressive) battle (in China). It also absorbed several hundred thousand repatriated soldiers who had accumulated raw experiences of China and its battlefields" (Yoshiaki 2015, p.87; parentheses by the authors). Many brought back diaries in which they had recorded these experiences. Some of the diaries were made public after the war ended in 1945 (Mark 2015, p. 15).

Drawing largely on these diaries and other personal documents written during or shortly after the war (Mark 2015, pp. 15-16), Yoshiaki Yoshimi conducted a nuanced, critical yet compassionate examination of personal war experiences of these repatriated soldiers. He published his findings in 1987 [For the English editions of his works on this topic, see Yoshimi (2012, 2015); For an intellectual biography of

\footnotetext{
12 The second Sino-Japanese war is a term used primarily by scholars outside China. It is also known as "the 14-year War of Resistance Against Japanese Aggression (1931-1945)" by Chinese historians (Sun 2017; Sino Japanese wars 2018). For perspicuous reviews of the war, see Fan (2016, pp. 165-231) and Mark (2015). In China, the war had long been referred to as "the 8-year War of Resistance against Japanese Aggression (1937-1945)" until recently. In 2017, Chinese historians reached a consensus that the resistance began in as early as 1931 in Northeast China right after the September 18 Incident (also known as Manchurian Incident among historians outside China); and that the resistance lasted 14 years till September 2, 1945 when Japan's unconditional surrender was formally signed (Sun 2017).
}

Yoshiaki Yoshimi, including an introduction of the research process he went through for this project, see Mark (2015)]. Besides graphic descriptions of the soldiers' atrocious behaviors in implementing the notorious "Three Alls Policy" ["kill all, loot all, and burn all"-Fan (2016, p. 183)], he found two common themes in these diaries. One is "a deepseated fear towards the total Chinese popular resistance and the feeling that the war was not easy" (Yoshiaki 2012, p. 125 , p. 129), and the other "a pointless, misplaced sense of superiority ... in dealing with Chinese people" (Ibid., p. 112). He wrote (Yoshiaki 2015; italics and parentheses by the authors),

(These repatriated soldiers) had developed a deep fear of the Chinese resistance that involved the country's entire people, ... whose solidarity extended to the elderly, women, and children" (Ibid., p. 87, p. 78). ${ }^{13}$ "[T]he fierce, relentless war against the Japanese (aggression) far surpassed (their) expectations ... (and was) difficult (for them) to comprehend according to what had been Japanese popular "common sense" (of their superiority over China and other Asian nations) (Ibid., p. 78).

Admittedly, being surprised and puzzled with the sheer tenacity of Chinese resistance, these repatriated Japanese soldiers were not alone-so were the Americans who had long been sympathetic and eventually, in 1942, became an important ally fighting shoulder to shoulder with the Chinese. ${ }^{14}$ To many if not most of them, it was almost incomprehensible that the undergirding solidarity, defiance, and readiness for self-sacrifice could burst out of a people who had been labeled as "the sick man of east Asia" (“东亚病夫”) by the Western powers since the late nineteenth century after the

\footnotetext{
13 Such solidarity also extended to the foreigners in China who compassionately joined the resistance. Among those who are well known and highly respected are Canadian physician Henry Norman Bethune [Chinese name白求恩, (1890-1939)] and Lebanese-American physician Shafick George Hatem [Chinese name马海德, (1910-1988)]. But there are many more. For example, in her 1997 best seller The rape of Nanking: the forgotten holocaust of World War II, Chinese American author Iris Chang [张纯如, (1968-2004)] tells the moving story of a group of foreigners during the 6-week Nanking Massacre (December, 1937-January 1938) [Nanking in Wade-Giles system is equivalent to Nanjing in Pinying system]. Led by John Rabe, a German businessman and, ironically, the leader of the Nazi Party in Nanking, they created and guarded the International Safety Zone which saved almost 300,000 Chinese lives (Chang 1997, pp. 105-139). Nanking people regard them as heroes, and John Rabe "the living buddha of Nanking" (Ibid, p. 109). Iris Chang praises John Rabe as "the Oskar Schindler of China." (Ibid.).

14 On December 8, 1941, the day after Japan attacked Pearl Harbor, the United States Congress declared war against Japan. Beginning in 1942, China and the USA formed a strong alliance against Japan that dramatically changed the course of the war (Fan 2016, p. 183).
} 
Opium Wars. ${ }^{15}$ Taking note of this was American sinologist Owen Lattimore (1900-1989), whose intellectual work and life experience "strongly shaped American public opinion toward China and Central Eurasia in the twentieth century" (Perdue 2018). ${ }^{16}$ In Our Chinese ally, a 1944 pamphlet prepared for the United States Armed Forces Institute (American Historical Association Historical Service Board 1944), Owen Lattimore and his wife Eleanor write (Ibid., p. 57):

China's heroic resistance to the modern military might of Japan has caused many of us to wonder in astonishment how such a non-industrialized, loosely organized nation could carry on as it has. We have been inclined to accept the continued resistance of the Chinese as an unexplainable miracle.

Throughout Chinese history, it is indeed this sort of recurring "unexplainable miracle" in the eyes of admirers, or haunting "deep-seated fear" in the minds of enemies, that has saved the nation many times (Fan 2016; Makeham 2008). Suffice it to say, fighting common threats collectively, be they from natural disaster or human conflict, has been, and will continue to be, a signature hallmark of this oldest living civilization in the world.

\section{What has enabled the Chinese people to fight common threats collectively many times?}

In asking this question, we share a similar curiosity with Owen and Eleanor Lattimore who ask the intriguing question in their 1944 pamphlet: "What is there about the

\footnotetext{
15 [1] The label became almost obsolete after the establishment of the People's Republic of China in 1949, with Chairman Mao Zedong's famous proclamation that'The Chinese people have stood up" (Lau 2008; Mao 1949). Among rare posterior incidences is the case in which Wall Street Journal's columnist Walter Russell Mead used the label in an opinion piece on February 3, 2020 (Mead 2020). The title China is the real sick man of Asia: its financial markets may be even more dangerous than its wildlife markets was regarded by the Chinese government as "a racially discriminatory title, triggering indignation and condemnation among the Chinese people", and resulted in a strong diplomatic action by the Chinese government (Hjelmgaard 2020). [2] "Opium Wars: two wars (1839-42; 1856-60) between China and Britain resulting from the Chinese refusal to allow the importation of opium from India. China ceded Hong Kong after the British victory in 1842. The British and French victory in the second war established free trade in Chinese ports and the legalization of the opium trade." (Collins Online Dictionary 2020).

${ }^{16}$ For those who are interested in Owen Lattimore's life and work, American historian Peter Perdue provides a succinct and useful introduction (Perdue 2018).
}

Chinese that has enabled them to resist Japan for seven years, almost with their bare hands?" (American Historical Association Historical Service Board 1944, p. 1) ${ }^{17}$ Their answer: "[M]oral and spiritual forces"(Ibid., p. 57)_,"values of culture" that "have existed in China so long ... (and) have soaked right through the whole people" (Ibid., p. 21). They regard having these long-standing cultural values "a very real advantage" of the Chinese people (Ibid.).

We concur. In fighting common threats to their survival and well-being, Chinese people's deep commitment to taking collective action, in the forms of solidarity, participation, discipline, and readiness for self-sacrifice, as showcased briefly in this article, is simply a natural outgrowth, a manifestation, of a strong cultural belief in collectivism they hold for thousands of years. ${ }^{18}$ Best exemplifying this deep commitment and its undergirding, long-standing cultural belief in collectivism is the song March of the volunteers (The State Council 2018). Written and composed in 1935 by Chinese playwriter Tian Han (田汉) and composer Nie Er (聂耳) during the 14-year War of Resistance Against Japanese Aggression (1931-1945), the song has ever since been inspirational to the Chinese people from all walks of life, so much so that it was adopted as the national anthem in 1949 for the newly established People's Republic of China (Ibid.). Below are the lyrics (Ibid.; italics by the authors of this article to highlight expressions of both the collectivist

\footnotetext{
17 [1] The official authorship of the pamphlet is American Historical Association Historical Service Board, as printed on the pamphlet. But on American Historical Association's web page, it is indicated that the pamphlet is written "By Owen and Eleanor Lattimore" (https:// www.historians.org/about-aha-and-membership/aha-history-and-archi ves/gi-roundtable-series/pamphlets/em-42-our-chinese-ally-(1944) accessed April 24, 2020). Following this fine-grain, official clarification, we acknowledge the two writers here. [2] The Lattimores apparently follow the 8-year war convention (see footnote 12).

18 [1] Collectivism is unquestionably among the perpetual cultural beliefs in China (Hofstede 2001, p. 211; Wong 2009, p. 152, p. 155; Yau 1988 pp. 44-45). In a 2009 essay for Encyclopedia of positive psychology, Chinese-Canadian psychologist Paul PT Wong posits that six strong cultural beliefs and a concomitant set of signature virtues have enabled the Chinese people to be culturally resilientprevail in the calamity and thrive in the aftermath-for more than 5000 years (Wong 2009, p. 152, p. 155). Besides collectivism, these cultural beliefs are uncontrollability of the world, ubiquity of change, fatalism, dualism, and utility of efforts (Ibid., pp. 152-154). Virtues derived from collectivism include collaboration, altruism, and social capital (Ibid., p. 155). [2] Cultural beliefs are conceptions about the world and human life a group of people hold as true, important, and desirable for good life (Edwards and Jarrett 2009, p. 265; Greif 1994, p. 915; Wong 2009, p. 152). Cultural beliefs influence how people think, what they value, and how they behave and cope (Fan 2000, p. 4; Greif 1994, p. 915; Wong 2009, p. 148).
} 
commitment in the face of a calamity and the cultural belief in collectivism; for audio track, go to http://english.www. gov.cn/audio).

\section{March of the volunteers}

Arise, we who refuse to be slaves!

With our very flesh and blood,

Let us build our new Great Wall!

The peoples of China are at their most critical time,

Everybody must roar defiance.

Arise! Arise! Arise!

Millions of hearts with one mind,

Brave the enemy's gunfire,

March on!

Brave the enemy's gunfire,

March on! March on! March on, on!

\section{Nothing as inspirational as a good example}

To conclude, it should be noted that taking collective action in fighting common threats is an innate human ability essential for survival and well-being. Throughout human history, there is a myriad of powerful examples from around the world in which people's deep commitment to taking collective action made decisive difference in fighting common threats, be they from natural disaster or human conflict. Examples of this kind, including those showcased above, are invaluable heritages that belong to the entire humanity. "There is nothing as inspirational as a good example" (Xiang 2020, p. 126) - by throwing sharp light on the power of taking collective action in fighting common threats, these examples help build a greater sense of optimism among all the people in the world both in the present fight against the COVID-19 pandemic and beyond.

Acknowledgements We are grateful to five anonymous reviewers for their constructive comments on an earlier version of the article; we thank Erika Boardman and Patricia Quinn (The Atkin Library, University of North Carolina at Charlotte, USA) for their valuable assistance during the preparation of this article.

\section{References}

American Historical Association Historical Service Board (1944) Our Chinese ally. War Department, Washington, D.C. https:// archive.org/details/OurChineseAlly/mode/2up (the whole book, Accessed 24 April 2020) and https://www.historians.org/about -aha-and-membership/aha-history-and-archives/gi-roundtable -series/pamphlets/em-42-our-chinese-ally-(1944). Accessed 24 April 2020

Brown KV, Sink J (2020) Trump's comment on disinfectant prompts experts to warn against inhaling bleach to kill coronavirus. TIME,
April 24, 2020 3:56 am EDT. https://time.com/5826882/coron avirus-trump-heat-bleach/. Accessed 27 April 2020

Campbell C (2020) These delivery drivers are risking their health to keep China running during the coronavirus epidemic. TIME, March 16, 2020 https://time.com/5803803/china-delivery-drive r-ecommerce-covid19/. Accessed 27 April 2020

Chang I (1997) The rape of Nanking: the forgotten holocaust of World War II. BasicBooks, New York

Chen L, Yuan X (2020) China's ongoing battle against the coronavirus: why did the lockdown strategy work well? Socio-Ecological Practice Research. https://doi.org/10.1007/s42532-020-00048-1

Chik H (2020) Coronavirus: China wants to lead the fight against Covid-19, but can it overcome the mistrust? South China Morning Post, April 26, 2020 https://www.scmp.com/print/news/china /diplomacy/article/3081543/coronavirus-china-wants-lead-fight -against-covid-19-can-it. Accessed 15 May 2020

China.org.cn (2020) Patriotic Health Campaign: Chinese pioneering undertaking in health field. China.org.cn http://www.china.org.cn/ china/2020-04/14/content_75929407.htm. Accessed 4 May 2020

Collins Online Dictionary (2020) Opium wars. Collins Online Dictionary https://www.collinsdictionary.com/dictionary/english/opium -wars. Accessed 10 May 2020

Douglas I (2020) COVID-19 compassion in self-isolating old age: looking forward from family to regional and global concerns. Socio Ecol Pract Res. https://doi.org/10.1007/s42532-020-00053 $-4$

Dozier K (2020) China wins: Why Trump's WHO funding cut is a gift to Beijing. TIME, April 15, 2020 10:34 pm EDT, https://time. com/5822078/china-wins-trumps-who-funding-cut/. Accessed 5 May 2020

Edwards LM, Jarrett KM (2009) Cultural values. In: Lopez SJ (ed) Encyclopedia of positive psychology. Wiley-Blackwell, Malden, pp 265-266

EndCoronavirus (2020) Some are winning: some are not: which countries do best in beating COVID-19? Endcoronavirus.org, https:// www.endcoronavirus.org/countries. Accessed 15 May 2020

Fan Y (2000) A classification of Chinese culture. Cross Cult Manag Int J 7(2):3-10

Fan CF (2016) Culture, institution, and development in China: the economics of national character. Routledge, New York

Graham-Harrison E, Kuo L (2020) China's coronavirus lockdown strategy: brutal but effective. The Guardian, https://www.theguardia n.com/world/2020/mar/19/chinas-coronavirus-lockdown-strategybrutal-but-effective. Accessed 28 March 2020

Greif A (1994) Cultural beliefs and the organization of society: a historical and theoretical reflection on collectivist and individualist societies. J Polit Econ 102(5):912-950

Hjelmgaard K (2020) China expels Wall Street Journal reporters over "racist" headline on coronavirus. USA Today Feb. 19, 2020 2:59 pm ET https://www.usatoday.com/story/news/world /2020/02/19/china-expels-wall-street-journal-reporters-over-racis t-headline/4804324002/. Accessed 10 May 2020

Hofstede G (2001) Culture's consequences: comparing values, behaviors, institutions, and organizations across nations, 2nd edn. Sage, Thousand Oaks

Hu R (2020) Reinventing community in COVID-19: a case in Canberra, Australia. Socio Ecol Pract Res. https://doi.org/10.1007/ s42532-020-00055-2

Huang Y (2004) The SARS epidemic and its aftermath in China: a political perspective. In: Knobler S, Mahmoud A, Lemon S et al (eds) Learning from SARS: preparing for the next disease outbreak-workshop Summary. The National Academies Press, Washington, DC, pp 116-136

Lau N-K (2008) The Chinese people have truly stood up. South China Morning Post; Hong Kong [Hong Kong], Aug 14, 2008 
Knobler S, Mahmoud A, Lemon S, et al. (Eds) (2004) Learning from SARS: preparing for the next disease outbreak-Workshop Summary. The National Academies Press, Washington, DC http:// www.nap.edu/catalog/10915.html. Accessed 4 May 2020

Liu X (2020) China has valuable lessons for the world in how to fight Covid-19: stigmatising the country only distracts from the global effort needed to beat the Pandemic. Financial Times, April 28, $2020 \mathrm{https}: / / \mathrm{www} . f t . c o m /$ content/ad61f0ea-8887-11ea-a109483c62d17528. Accessed 15 May 2020

Mahmoud AAF, Lemon SM (2004) Summary and assessment. In: Knobler S, Mahmoud A, Lemon S et al (eds) Learning from SARS: preparing for the next disease outbreak-workshop summary. The National Academies Press, Washington, DC, pp 1-39

Makeham J (2008) China: the world's oldest living civilization revealed. Thames \& Hudson, London

Mao Z (1949) The Chinese people have stood up! In: Marxist.org (1969): Selected works of Mao Tse-Tung, Vol V. https://www. marxists.org/reference/archive/mao/selected-works/volume-5/ index.htm. Accessed 10 May 2020

Mark E (2015) Translator's introduction: the people in the war. In: Yoshiaki Y (2015) Grassroots fascism: the war experience of the Japanese people. Translated and annotated by Ethan Mark, 1-39. Columbia University Press, New York

Mead WR (2020) China is the real sick man of Asia: its financial markets may be even more dangerous than its wildlife markets. The Wall Street Journal, Feb. 3, 2020 6:47 pm ET https://www.wsj. com/articles/china-is-the-real-sick-man-of-asia-11580773677. Accessed 10 May 2020

Merriam-Webster (2020a) COVID-19. In: Merriam-Webster.com dictionary. https://www.merriam-webster.com/dictionary/COVID -19. Accessed 27 April 2020

Merriam-Webster (2020b) Trending: "sarcasm," "sarcastic" lookups spiked $900 \%$ on April 24, 2020. In: Merriam-Webster.com dictionary. https://www.merriam-webster.com/news-trend-watch/ trump-i-was-being-sarcastic-20200424. Accessed 27 April 2020

Merriam-Webster (2020c) SARS. In: Merriam-Webster.com dictionary. https://www.merriam-webster.com/dictionary/SARS. Accessed 5 May 2020

Perdue PC (2018) Owen Lattimore: world historian. Oxford Handbooks Online, Oxford University Press www.oxfordhandbooks .com. Accessed 24 April 2020

Sino Japanese wars (2018) In Helicon (Ed.) The Hutchinson unabridged encyclopedia with atlas and weather guide. [Online]. Abington, Helicon

Smith D (2020) Coronavirus: medical experts denounce Trump's theory of "disinfectant injection". The Guardian, April 24, 2020 https://www.theguardian.com/world/2020/apr/23/trump-coron avirus-treatment-disinfectant. Accessed 27 April 2020

Smith D, Paul K (2020) Debacle of Trump's coronavirus disinfectant comments could be tipping point. The Guardian, April 25, 2020 https://news.yahoo.com/debacle-trumps-coronavirus-disinfecta nt-comments-130714117.html. Accessed 27 April 2020

Sun J (2017) 14-year War of Resistance Against Japanese Aggression a consensus among Chinese historians. People's Daily Online, 17:24, January 11, 2017. http://en.people.cn/ n3/2017/0111/c90000-9165703.html. Accessed 30 March 2020

The Associate Press (2020) China delayed releasing coronavirus info, frustrating WHO. https://apnews.com/3c061794970661042b18 d5aeaaed9fae. Accessed 2 June 2020

The Dalai Lama (2020) "Prayer is not enough." The Dalai Lama on why we need to fight coronavirus with compassion. TIME, April 14, 2020 5:23 pm EDT, https://time.com/5820613/dalai-lamacoronavirus-compassion/. Accessed 22 May 2020

The Joint Mission (2020) Report of the WHO-China Joint Mission on Coronavirus Disease 2019 (COVID-19), 16-24 February 2020.
World Health Organization (WHO). https://www.who.int/docs/ default-source/coronaviruse/who-china-joint-mission-on-covid -19-final-report.pdf. Accessed 24 April 2020

The State Council (2018) National anthem. The State Council of the People's Republic of China, english.gov.cn, http://english.www. gov.cn/audio. Accessed 9 May 2020

Wang Y (2020) China's ongoing battle against the coronavirus: a scholar-practitioner's experiences and reflections. Soc-Ecol Pract Res. https://doi.org/10.1007/s42532-020-00047-2

Wong PTP (2009) Chinese positive psychology. In: Lopez SJ (ed) Encyclopedia of positive psychology. Wiley-Blackwell, Malden, pp 148-156

Xiang W-N (2019) The Red Flag Canal: a socio-ecological practice miracle from serendipity, through impossibility, to reality. Soc-Ecol Pract Res 2(1):105-110. https://doi.org/10.1007/s42532-019-00037-z

Xiang W-N (2020) From good practice for good practice we theorize; in small words for big circles we write. Soc-Ecol Pract Res 2(1):121-128. https://doi.org/10.1007/s42532-020-00040-9

Yau OHM (1988) Chinese cultural values: their dimensions and marketing implications. Eur J Mark 22(5):44-57

Yoshiaki Y (2012) The Second Sino-Japanese War and national mobilization: the issue of rallying soldiers and personal experiences of the battlefield. Translated by Miriam Chusid. Japan Forum, 24(1): 119-130, https://doi.org/10.1080/09555803.2011.637638 (First published in Japanese in 1987)

Yoshiaki Y (2015) Grassroots fascism: the war experience of the Japanese people. Translated and annotated by Ethan Mark. Columbia University Press, New York (First published in Japanese by University of Tokio press in 1987)

Zou S (2020) Project shows faces behind the masks. chinadaily. com.cn I Updated: 2020-04-21 06:15, https://www.chinadaily .com.cn/a/202004/21/WS5e9daea2a3105d50a3d1784d_1.html. Accessed 25 April 2020

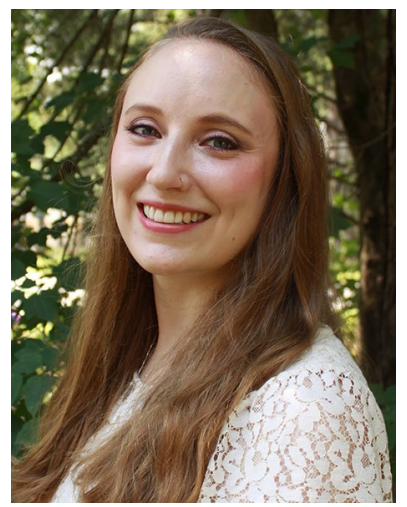

Hannah Catherine Palko is a $\mathrm{Ph} . \mathrm{D}$. student at the University of North Carolina at Charlotte, Department of Geography and Earth Sciences. She holds a master of science in ecology from the University of North Carolina at Chapel Hill. Her research interests center around compassionate socio-ecological practices, specifically in death care.

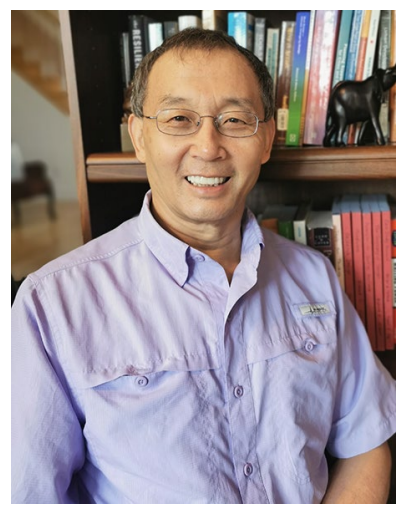

Wei-Ning Xiang is a professor of geography and earth sciences at the University of North Carolina at Charlotte, USA (1990-present); the former co-editor-inchief of Landscape and Urban Planning (2011-2018); and the founding editor-in-chief of Socio-Ecological Practice Research (SEPR). 